\title{
Africans Who Arrive in the United States before 20 Years of Age Maintain Both Cardiometabolic Health and Cultural Identity: Insight from the Africans in America Study
}

\author{
Elyssa M. Shoup ${ }^{1,+}$, Thomas Hormenu ${ }^{1,+}{ }^{+}$, Nana H. Osei-Tutu ${ }^{1}$, M. C. Sage Ishimwe ${ }^{1,2,3}$, \\ Arielle C. Patterson ${ }^{1}$, Christopher W. DuBose ${ }^{1}$, Annemarie Wentzel ${ }^{1}$, \\ Margrethe F. Horlyck-Romanovsky ${ }^{4}\left(\mathbb{D}\right.$ and Anne E. Sumner ${ }^{1,2, *}$ \\ 1 Section on Ethnicity and Health, Diabetes, Endocrinology, and Obesity Branch, National Institute of Diabetes \\ and Digestive and Kidney Diseases, Bethesda, MD 20892, USA; elyssa.shoup@nih.gov (E.M.S.); \\ thormenu@ucc.edu.gh (T.H.); nana.osei-tutu@nih.gov (N.H.O.-T.); sishimwe@ughe.org (M.C.S.I.); \\ pattersonarc@niddk.nih.gov (A.C.P.); christopher.dubose@nih.gov (C.W.D.); \\ annemarie.wentzel.aw@gmail.com (A.W.) \\ 2 National Institute of Minority Health and Health Disparities, Bethesda, MD 20892, USA \\ 3 Institute of Global Health Equity Research, University of Global Health Equity, Kigali 6955, Rwanda \\ 4 Department of Health and Nutrition Sciences, Brooklyn College, City University of New York, New York, \\ NY 11210, USA; MargretheHR@brooklyn.cuny.edu \\ * Correspondence: Anne.Sumner@nih.gov \\ + Co-first authors and contributed equally.
}

Received: 29 October 2020; Accepted: 11 December 2020; Published: 15 December 2020

check for updates

\begin{abstract}
The overall consensus is that foreign-born adults who come to America age $<20 \mathrm{y}$ achieve economic success but develop adverse behaviors (smoking and drinking) that lead to worse cardiometabolic health than immigrants who arrive age $\geq 20 \mathrm{y}$. Whether age of immigration affects the health of African-born Blacks living in America is unknown. Our goals were to examine cultural identity, behavior, and socioeconomic factors and determine if differences exist in the cardiometabolic health of Africans who immigrated to America before and after age $20 \mathrm{y}$. Of the 482 enrollees (age: $38 \pm 1$ (mean \pm SE), range: 20-65 y) in the Africans in America cohort, 23\% (111/482) arrived age $<20 \mathrm{y}$, and $77 \%$ (371/482) arrived age $\geq 20 \mathrm{y}$. Independent of francophone status or African region of origin, Africans who immigrated age $<20$ y had similar or better cardiometabolic health than Africans who immigrated age $\geq 20 \mathrm{y}$. The majority of Africans who immigrated age $<20 \mathrm{y}$ identified as African, had African-born spouses, exercised, did not adopt adverse health behaviors, and actualized early life migration advantages, such as an American university education. Due to maintenance of cultural identity and actualization of opportunities in America, cardiometabolic health may be protected in Africans who immigrate before age 20. In short, immigrant health research must be cognizant of the diversity within the foreign-born community and age of immigration.
\end{abstract}

Keywords: African immigrants; cardiometabolic health; socioeconomic status; stress

\section{Introduction}

Between 2010 and 2018, immigration from sub-Saharan Africa to the United States increased by $52 \%$ [1]. This is four times higher than the $12 \%$ increase in the overall rate of immigration to the United States [1]. African immigrants are well-educated and contribute to the workforce at a higher rate than other immigrant groups or native-born Americans [1,2], yet little is known about the cardiometabolic 
health of African immigrants. In addition, there is a paucity of data on how factors, such as age of immigration and cultural transition, influence their cardiometabolic health.

In adapting to life in the United States, African immigrants have to face many challenges, including the transition from a majority to a minority population and racial discrimination $[1,3,4]$. In short, international migration has both physiologic and psychological consequences and the potential to adversely affect cardiometabolic health [3-8]. Cardiometabolic health encompasses obesity, diabetes, dyslipidemia, and cardiovascular disease (CVD). CVD is a composite term for coronary heart, cerebrovascular and peripheral artery diseases, and heart failure [9].

While data on the health of African immigrants are scant and largely limited to self-report [4,10], extensive data on Hispanic immigrants are available [5,6,11-13]. Hispanic immigrants who arrive in the United States before age twenty are more likely to achieve English-proficiency, higher education, and economic prosperity than older immigrants [12]. However, immigrants who come to the United States at a young age are also more likely to smoke, drink alcohol and develop obesity than older immigrants $[5,6,11-13]$. Therefore, in adulthood the mortality rate for Hispanic immigrants who arrived in the United States before age 20 is higher than for those who arrived after 20 years of age [5,12].

For African immigrants, the influence of generation, behavior, and social conditions on cardiometabolic health as assessed by obesity status, diabetes prevalence, and cardiovascular risk are unknown. In addition, African region of origin and francophone status of birth country are rarely considered when evaluating the health of African immigrants to the United States. Therefore, we worked with the Africans in America cohort and collected cultural, socioeconomic, and immigration-specific data. The cultural and behavioral factors studied were ethnic identification, marriage to an African-born spouse, physical activity, smoking, and alcohol intake. Socioeconomic factors investigated were education, location of university attended, income, and health insurance. Immigration-specific factors included age at immigration, duration of residence in the United States, and African region and francophone status of the country of origin.

Our goals were to examine cultural identity, behavior, and socioeconomic factors and determine if there are differences in the cardiometabolic health of Africans who immigrated to the United States at less than 20 years of age (Immigration-Age $<20 \mathrm{y}$ ) compared to those who came to the United States at 20 years of age or greater (Immigration-Age $\geq 20 \mathrm{y}$ ).

\section{Materials and Methods}

The Africans in America cohort was designed to assess the cardiometabolic health of African-born Blacks living in the United States [14-17]. At enrollment, all participants were between the ages of 20 and 65 years. Recruitment was achieved with newspaper advertisements, announcements on the NIH website, flyers, presentations at community events, and referrals by previous participants. The protocol was approved by the NIDDK Institutional Review Board (Clinical Trials.gov Identifier: NCT00001853). Every participant gave written informed consent.

Telephone interviews were conducted prior to enrollment. Potential participants had to state that they self-identified as Black, were born in a sub-Saharan African country, and that their parents also self-identified as Black and were born in a sub-Saharan African country. In addition, potential participants had to self-identify as healthy and deny a history of diabetes.

Five hundred and twenty-two African-born Blacks living in metropolitan Washington, DC, completed the telephone interview and proceeded to Visit 1, which was an outpatient screening visit conducted at the NIH Clinical Center, Bethesda, Maryland. At the screening visit, social and medical histories were taken, and a physical examination, an electrocardiogram, and routine blood tests were performed. Forty individuals did not proceed from Visit 1 to Visit 2. Reasons for not proceeding to Visit 2 included screening laboratory identification of anemia, elevated liver transaminases, hypothyroidism, intravenous access issues, or scheduling challenges. 
As a result, 482 enrollees proceeded to Visit 2, which occurred $10 \pm 8$ days after Visit 1. At Visit 2, weight, height, blood pressure (BP), waist circumference (WC), a fasting lipid profile, A1C, and hemoglobin electrophoresis were measured, and an oral glucose tolerance test (OGTT) (Trutol 75, Custom Laboratories) was performed.

\subsection{BMI Status}

BMI was defined according to standard criteria (Normal weight: BMI 18.5 to $24.9 \mathrm{~kg} / \mathrm{m}^{2}$; Overweight: BMI 25.0 to $29.9 \mathrm{~kg} / \mathrm{m}^{2}$; Obesity: BMI $\geq 30 \mathrm{~kg} / \mathrm{m}^{2}$ ) [18].

\subsection{Diabetes}

Diabetes was diagnosed if $\mathrm{A} 1 \mathrm{C} \geq 6.5 \%$ or glucose criteria for the OGTT were met (fasting glucose $\geq 126 \mathrm{mg} / \mathrm{dL}$ and/or $2 \mathrm{~h}$ glucose $\geq 200 \mathrm{mg} / \mathrm{dL}$ ) [19].

\subsection{Determination Cardiovascular Disease Risk Score}

We used the 10-year Framingham Cardiovascular Disease Risk Score (CVD-Risk) because it was validated in African Americans and calculated based on a formula that used sex-specific thresholds for six parameters: age, smoking, systolic BP, total cholesterol, high density lipoprotein (HDL) cholesterol, and diabetes $[9,20]$.

\subsection{Social Variables}

Data for all participants were available for five variables which were dichotomized: education (college graduation rate), income ( $\geq 40 \mathrm{k} /$ year), smoking (Yes or No in the last year), alcohol intake (one or more drinks per week vs. less than once per week), and marital status. Marital status was defined as partnered (married or living with partner) or not partnered (never married, separated, divorced, or widowed) [4]. For duration of residence in the United States, data were missing for four individuals $(n=478)$. For five variables, data were collected consecutively from the most recently enrolled participants. The number of participants with data for each of these variables were physical activity $(n=270)$, self-categorization (African or African-American) $(n=255)$, ethnicity of spouse $(n=220)$, and location of university attended (United States, Africa or elsewhere) $(n=74)$. For the 220 individuals who were enrolled after the question about ethnicity of partner was initiated, 51\% (113/220) were partnered. Exercise intensity was determined by International Physical Activity Questionnaire categories and dichotomized as sedentary (IPAQ category Low) or active (IPAQ category Moderate or High) [21].

\subsection{Assays}

Hemoglobin and hematocrit were measured in EDTA-anticoagulated whole blood using a Sysmex XE-5000. Glucose, cholesterol, triglyceride, HDL, LDL, apolipoprotein A1 (apoA1), and apolipoprotein B (apoB) were measured in lithium-heparin plasma (Roche/Hitachi Cobas C, Roche Diagnostics, Indianapolis, IN, USA). A1C levels were determined by HPLC using National Glycohemoglobin Standardization Program (NGSP) [22]. Identities of hemoglobin proteins were confirmed by comparison with known samples of $\mathrm{HbA}, \mathrm{HbS}$, and $\mathrm{HbC}$.

\subsection{Statistical Analyses}

Unless stated otherwise, data are presented as mean \pm SE. The cohort was divided by immigration age into two groups: arrival before the age of 20 (Immigration-Age < $20 \mathrm{y}$ ) and arrival at age 20 or older (Immigration-Age $\geq 20 \mathrm{y}$ ). For sub-analyses, the Immigration-Age $<20$ y group was further divided into two groups: Immigration-Age $<10$ y and Immigration-Age-10-to-19-y. Comparisons were by unpaired $t$-tests or one-way ANOVA with Bonferroni correction for continuous variables and by 
chi-square tests for categorical variables. Comparisons of the two immigration groups of all biological parameters, including BMI, WC, blood pressure, lipids, and CVD-Risk score, were adjusted for age.

In addition, multiple linear regressions were performed separately for the Immigration-Age $<20 \mathrm{y}$ and Immigration-Age $\geq 20$ y groups. The dependent variable was CVD-Risk, and the independent variables were age of immigration, duration of US residence, health insurance, education, income, and alcohol intake. Smoking was not included as an independent variable as smoking status is included in the calculation of the CVD-Risk [9]. For the Immigration-Age $\geq 20$ y group, duration of United States residence was divided into five-year increments ( 0 to $4 \mathrm{y}, 5$ to $9 \mathrm{y}, 10$ to $14 \mathrm{y}, 15$ to $19 \mathrm{y}$ and 20 years plus). For the Immigration-Age $<20$ y group, duration of United States residence intervals were: 0 to $9 \mathrm{y}, 10$ to $14 \mathrm{y}, 15$ to $19 \mathrm{y}$, and 20 years plus. The 0 to $4 \mathrm{y}$ and 5 to $9 \mathrm{y}$ intervals were combined, because there were only two individuals in the Immigration-Age $<20$ y group who had been in the United States for less than five years.

$p$-Values $\leq 0.05$ were considered significant. Data were managed with Research Electronic Data Capture (REDCap) [23]. Analyses were performed with STATA16 (College Station, TX, USA).

\section{Results}

The 482 participants (male: 65\%; age: $38 \pm 0.1$ y, range 20 to 65 y; BMI: $27.6 \pm 0.2 \mathrm{~kg} / \mathrm{m}^{2}$, range 18.2 to $42.4 \mathrm{~kg} / \mathrm{m}^{2}$ ) were from four areas of sub-Saharan Africa: West (52\%, 253/482), Central $(20 \%, 96 / 482)$, East $(28 \%, 133 / 482)$, and South $(<1 \%, 4 / 482)$. The four participants from Southern African countries were included in the Central African group (Supplement Table S1). Comparison by African region of origin revealed no differences in socioeconomic, cardiometabolic, or cultural factors including gender, age, age at immigration, or frequency of self-identification as African. However, West Africans had the longest residence in the United States. In addition, heterozygous hemoglobinopathies (i.e., sickle cell trait and hemoglobin C trait) were more common in West and Central Africans than East Africans.

When the cohort was analyzed according to whether the country of origin was francophone $(34 \%$, 162/482) or non-francophone $(66 \%, 320 / 482)$ (Figure 1), immigrants from francophone countries were older at immigration ( $29 \pm 1$ vs. $25 \pm 1 \mathrm{y}, p=0.002)$ and had been in the United States for a shorter duration (10 \pm 1 vs. $13 \pm 1 \mathrm{y}, p<0.001)$ (Supplement Table S2).

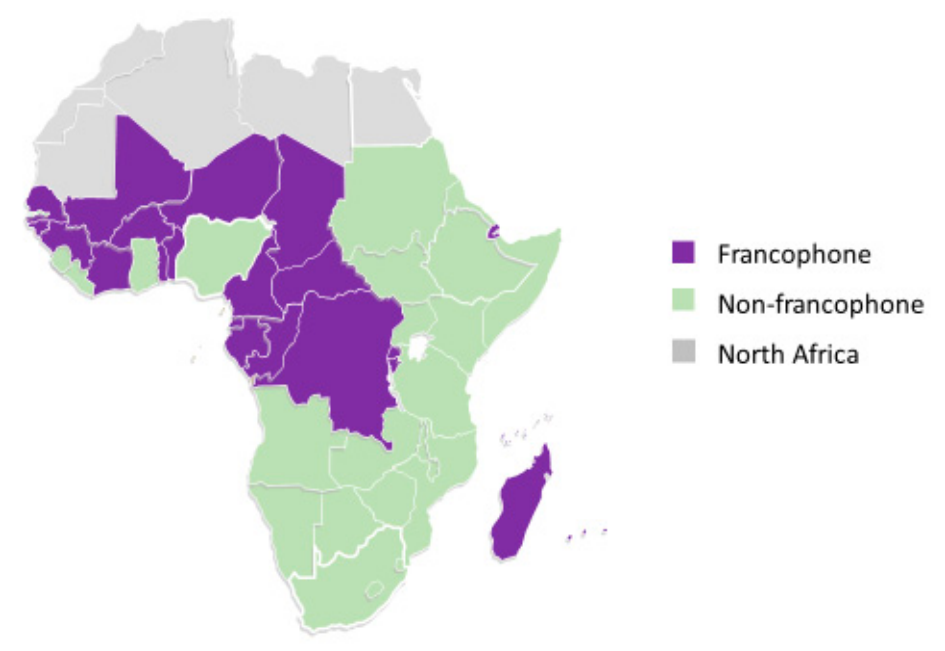

Figure 1. Geographical Distribution of Sub-Saharan African Countries by Francophone Status.

However, as with geographic region, there were no significant differences in cultural identity, behavior, and socioeconomic factors. In addition, differences by immigration age group were similar in the francophone and non-francophone subgroups (Supplement Tables S3 and S4). Therefore, the cohort was analyzed without regard to African region of origin or francophone status of birth country. 


\subsection{Age, Temporal and Gender Characteristics}

Twenty-three percent (111/482) of participants were in the Immigration-Age $<20$ y group and $77 \%$ (371/482) in the Immigration-Age $\geq 20$ y group (Table 1$)$.

Table 1. Characteristics by Immigration Age Group.

\begin{tabular}{|c|c|c|c|c|}
\hline Parameters $^{1}$ & $\begin{array}{c}\text { Total } \\
n=482 \\
100 \%\end{array}$ & $\begin{array}{c}\text { Immigration Age } \\
\text { Less than } 20 \mathrm{y} \\
n=111 \\
23 \%\end{array}$ & $\begin{array}{c}\text { Immigration Age } \\
20 \text { to } 65 \mathrm{y} \\
n=371 \\
77 \%\end{array}$ & $p$-Value ${ }^{2}$ \\
\hline Current Age $(y)^{3}$ & $38 \pm 1$ & $31 \pm 1$ & $40 \pm 1$ & $<0.001$ \\
\hline Age at immigration (y) & $26 \pm 1$ & $12 \pm 1$ & $31 \pm 1$ & $<0.001$ \\
\hline Duration of Residence in US (y) & $12 \pm 1$ & $24 \pm 1$ & $8 \pm 1$ & $<0.001$ \\
\hline Male (\%) & $65 \%$ & $53 \%$ & $69 \%$ & 0.003 \\
\hline Obesity (\%) & $27 \%$ & $23 \%$ & $29 \%$ & 0.209 \\
\hline Diabetes $(\%)^{3}$ & $7 \%$ & $4 \%$ & $8 \%$ & 0.123 \\
\hline CVD-Risk (\%) & $3.69 \pm 0.21$ & $3.94 \pm 0.35$ & $3.62 \pm 0.18$ & 0.413 \\
\hline BMI $\left(\mathrm{kg} / \mathrm{m}^{2}\right)$ & $27.6 \pm 0.2$ & $27.6 \pm 0.4$ & $27.6 \pm 0.2$ & 0.962 \\
\hline $\mathrm{WC}(\mathrm{cm})$ & $90.7 \pm 0.5$ & $90.5 \pm 1.1$ & $90.8 \pm 0.6$ & 0.818 \\
\hline Systolic BP $(\mathrm{mmHg})^{3}$ & $120 \pm 1$ & $119 \pm 1$ & $120 \pm 1$ & 0.410 \\
\hline Diastolic BP (mmHg) & $72 \pm 1$ & $72 \pm 1$ & $72 \pm 1$ & 0.664 \\
\hline Pulse (beat/min) & $67 \pm 1$ & $68 \pm 1$ & $67 \pm 1$ & 0.910 \\
\hline Cholesterol (mg/dL) ${ }^{3}$ & $164 \pm 2$ & $164 \pm 3$ & $164 \pm 2$ & 0.778 \\
\hline $\mathrm{HDL}(\mathrm{mg} / \mathrm{dL})(\mathrm{male})^{3}$ & $50 \pm 1$ & $52 \pm 2$ & $47 \pm 1$ & 0.014 \\
\hline $\operatorname{HDL}(\mathrm{mg} / \mathrm{dL})(\text { female })^{3}$ & $57 \pm 1$ & $59 \pm 2$ & $57 \pm 1$ & 0.382 \\
\hline $\mathrm{TG}(\mathrm{mg} / \mathrm{dL})$ & $73 \pm 2$ & $67 \pm 4$ & $75 \pm 2$ & 0.062 \\
\hline LDL (mg/dL) & $98 \pm 1$ & $96 \pm 3$ & $99 \pm 2$ & 0.486 \\
\hline apoA1 (mg/dL) (male) & $129 \pm 1$ & $135 \pm 3$ & $128 \pm 1$ & 0.015 \\
\hline apoA1 (mg/dL) (female) & $141 \pm 2$ & $144 \pm 3$ & $140 \pm 2$ & 0.260 \\
\hline apoB (mg/dL) & $82 \pm 1$ & $81 \pm 2$ & $83 \pm 1$ & 0.589 \\
\hline Identify as African $(n=255)$ & $91 \%$ & $89 \%$ & $92 \%$ & 0.568 \\
\hline Partnered (\%) ${ }^{4}$ & $48 \%$ & $29 \%$ & $54 \%$ & $<0.001$ \\
\hline African-born Partner $(\%)(n=113)$ & $76 \%$ & $56 \%$ & $80 \%$ & 0.026 \\
\hline Physical Activity $(n=270)^{5}$ & $81 \%$ & $89 \%$ & $78 \%$ & 0.040 \\
\hline Smoker ${ }^{3}$ & $5 \%$ & $5 \%$ & $5 \%$ & 0.814 \\
\hline Alcohol $\geq 1$ drink/week & $26 \%$ & $32 \%$ & $24 \%$ & 0.111 \\
\hline Income $\geq 40 \mathrm{k}$ & $48 \%$ & $53 \%$ & $47 \%$ & 0.228 \\
\hline College Graduate (\%) & $72 \%$ & $67 \%$ & $74 \%$ & 0.154 \\
\hline American University Degree $(n=74)$ & $61 \%$ & $100 \%$ & $37 \%$ & $<0.001$ \\
\hline Health Insurance (\%) & $68 \%$ & $78 \%$ & $65 \%$ & 0.007 \\
\hline
\end{tabular}

Health Insurance (\%)

${ }^{1}$ Data presented as mean \pm SE or percentages. ${ }^{2}$ For continuous variables, multiple regression were done to adjust for age, for categorical variables chi-square analyses were performed. ${ }^{3}$ Variables used to calculate CVD-Risk.

${ }^{4}$ Married or living with partner (alternative category: never married, separated, divorced, widowed). ${ }^{5}$ IPAQ

Category (Moderate or High) vs. (Low).

Participants who came before the age of $20 \mathrm{y}$ were younger ( $31 \pm 1$ vs. $40 \pm 1 \mathrm{y}, p<0.001$ ) and had been in the United States for longer ( $24 \pm 1$ vs. $8 \pm 1 \mathrm{y}, p<0.001$ ) (Table 1) (Figure 2).

Gender distribution differed by immigration age group, as percent male in the Immigration-Age $<20$ y group was lower than the percent male in the Immigration-Age $\geq 20$ y group, (53\% vs. $69 \%$, respectively) $(p=0.003)$. 


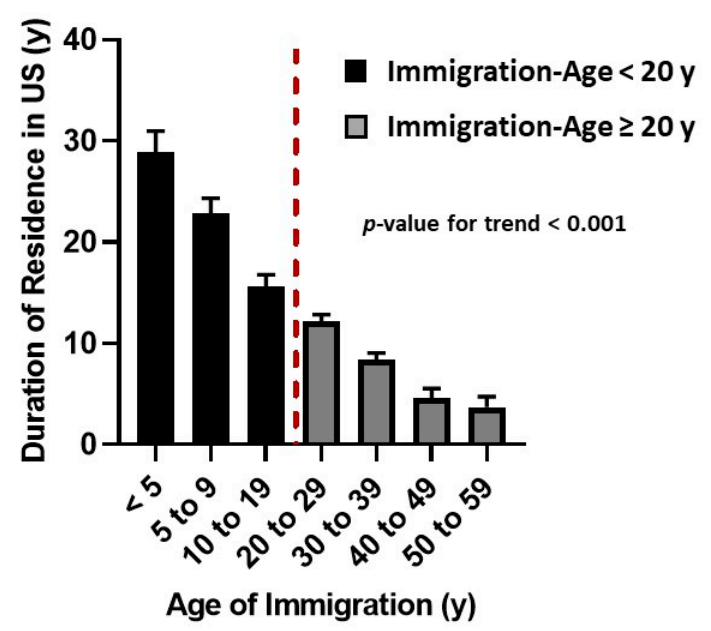

Figure 2. Duration of Residence in the United States by Age of Immigration. Dash red line separates the group who immigrated before age $20 \mathrm{y}$ from the group who immigrated at $20 \mathrm{y}$ or older.

\subsection{Cardiometabolic Health}

In the overall cohort, there was no significant difference by immigration age group in prevalence of obesity, diabetes or CVD-Risk. However, for men, the lipid profile was better for the Immigration-Age $<20$ y group than the Immigration-Age $\geq 20$ y group. Specifically, both HDL and apoA1 were higher in the Immigration-Age $<20$ y group than the Immigration-Age $\geq 20$ y group $(p=0.014$ and $p=0.015$, respectively), (Table 1 ). In addition, triglyceride concentration tended to be lower in the Immigration-Age $<20$ y group $(p=0.062)$ (Table 1$)$.

\subsection{Social Factors}

\section{Cultural Identity}

For the overall cohort, the rate at which participants self-identified as African was very high and did not differ by immigration age group ( $89 \%$ vs. $92 \%, p=0.568)$ (Figure $3 \mathrm{~A})$.
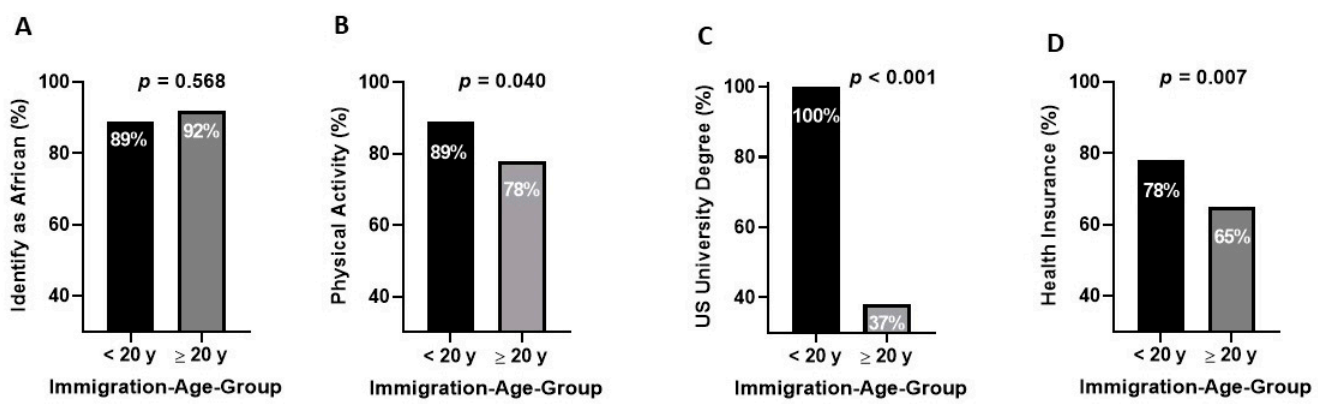

Figure 3. Comparison by Immigration-Age-Group of Key Cultural and Socioeconomic Factors. Black columns represent the Immigration-Age $<20$ y group. Grey columns represent the Immigration-Age $\geq$ 20 y group. (A): Self Identify as African; (B): Physical Activity; (C): Degree from a university in the United States; (D): Health Insurance.

When the overall cohort Immigration-Age $<20$ y group was subdivided into two groups: $<10$ years and 10 to 19 years, the rate of African self-identification was lower in the $<10$ years group than the 10 to 19 years group $(78 \%$ vs. $95 \%, p=0.035)$ (Table 2$)$. However, the majority of both groups self-identified as African. 
Table 2. Characteristics of the Immigration-Age $<20$ y Group.

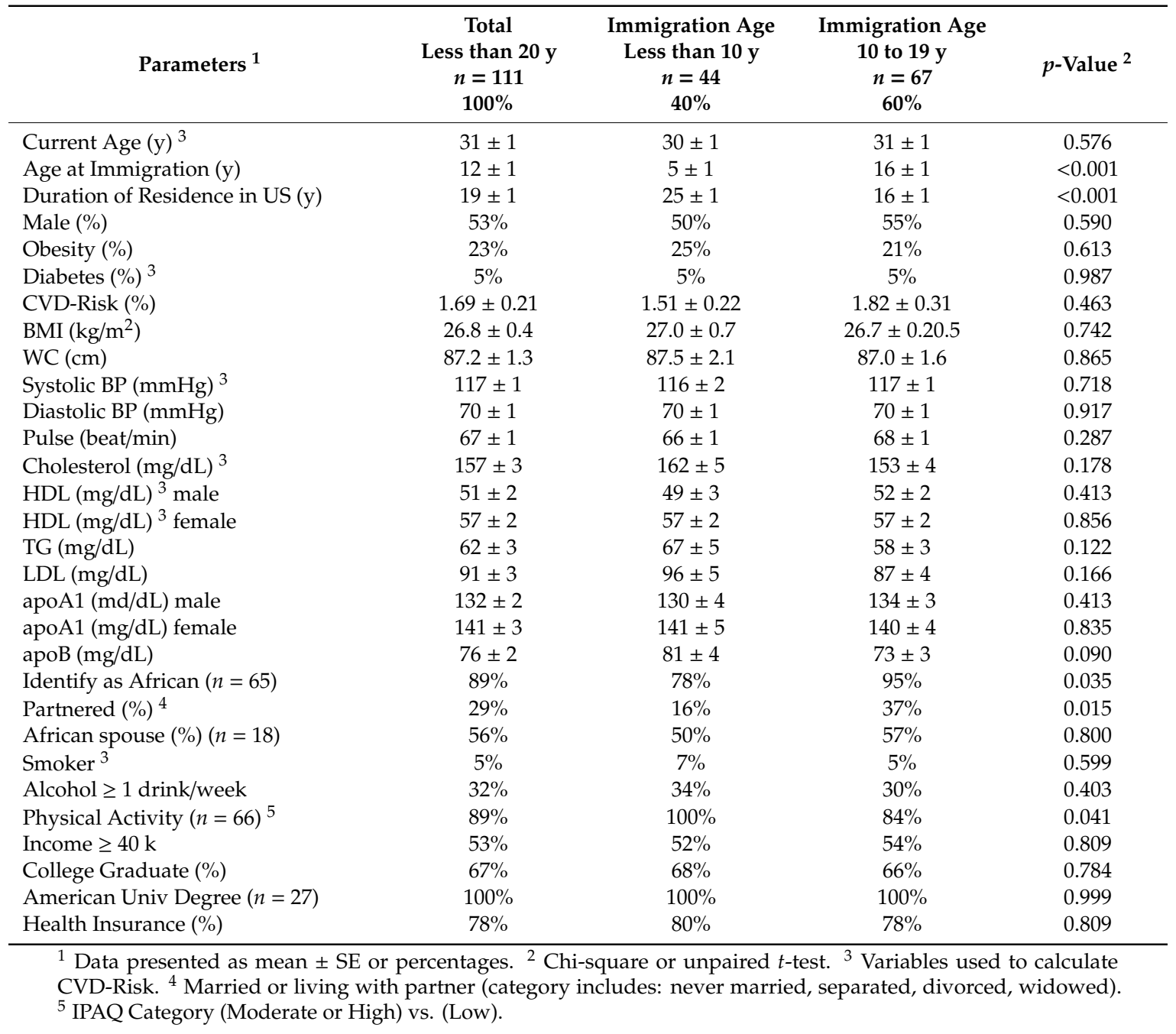

\subsection{Marital Status}

Among those who were married, the rate of marriage to an African-born spouse was lower in the Immigration-Age $<20$ y group than the Immigration-Age $\geq 20$ y group ( $56 \%$ vs. $80 \%, p=0.026$ ) (Table 1 ). However, more than $50 \%$ of married African immigrants in both groups had African-born spouses.

\subsection{Physical Activity, Smoking and Alcohol Intake}

The Immigration-Age $<20$ y group had a higher physical activity rate than the Immigration-Age $\geq 20$ y group ( $89 \%$ vs. $78 \%, p=0.040$ ) (Figure $3 \mathrm{~B}$ ).

Smoking and alcohol intake did not differ by immigration age group (Table 1).

\subsection{Socioeconomic Status}

Socioeconomic status as determined by income and college graduation rate were similar in the Immigration-Age $<20 \mathrm{y}$ and Immigration-Age $\geq 20$ y groups. Yet, one hundred percent of the Immigration-Age $<20$ y group with college degrees graduated from an American University, compared to only $37 \%$ for the Immigration-Age $\geq 20 \mathrm{y}(p<0.001$ ) (Figure 3C). The majority of both groups had health insurance, but health insurance coverage was more common in the Immigration-Age $<20 \mathrm{y}$ group than the Immigration-Age $\geq 20$ y group (78\% vs. 65\%, $p=0.007$ ) (Figure 3D). 
When the Immigration-Age $<20$ y group was divided into two groups (i.e., Immigration-Age $<10$ y and Immigration-Age-10-to-19-y), there was no difference between groups in income, college graduation rate, or health insurance (all $p>0.7$ ) (Table 2).

\subsection{The Combined Effect of Demographic, Socioeconomic, and Behavioral Factors on the CVD-Risk}

Multiple regressions were performed with CVD-Risk as the dependent variable and immigration age, duration of US residence, education, health insurance, income, and alcohol intake as independent variables. As smoking is a component of the CVD-Risk, it was not included in the regression models. As physical activity data were only available in $56 \%$ of participants, it was not included.

For the Immigration-Age $<20$ y group, adjusted $\mathrm{R}^{2}$ was $31 \%$. Only two variables significantly contributed to the overall model, age at immigration, and US residence for $\geq 20$ years (both $p<0.001$ ) (Table 3).

Table 3. Multiple Regression with CVD-Risk as the Dependent Variable in the Immigration-Age $<20 \mathrm{y}$ Group. Adjusted $\mathrm{R}^{2}: 31 \%(n=110)^{1}$.

\begin{tabular}{lccc}
\hline \multicolumn{1}{c}{ Independent Variable } & $\beta$-Coefficient & SE & $p$-Value \\
\hline Immigration Age & 0.200 & 0.039 & $<0.001$ \\
US residence 10 to $14 \mathrm{y}^{2}$ & 0.581 & 0.657 & 0.379 \\
US residence 15 to $19 \mathrm{y}^{2}$ & 0.880 & 0.565 & 0.123 \\
US residence 20 y plus ${ }^{2}$ & 3.620 & 0.624 & $<0.001$ \\
Education & -0.145 & 0.159 & 0.366 \\
Health Insurance & -0.158 & 0.438 & 0.719 \\
Income & -0.044 & 0.110 & 0.687 \\
Alcohol Intake & -0.147 & 0.387 & 0.706 \\
\hline
\end{tabular}

${ }^{1}$ One participant had missing data on duration of US residence. ${ }^{2}$ Reference group is US residence 0 to $9 \mathrm{y}$.

The duration of United States residence intervals of 10 to $14 \mathrm{y}$ and 15 to $19 \mathrm{y}$ did not contribute to the CVD-Risk (Figure 4A).

A

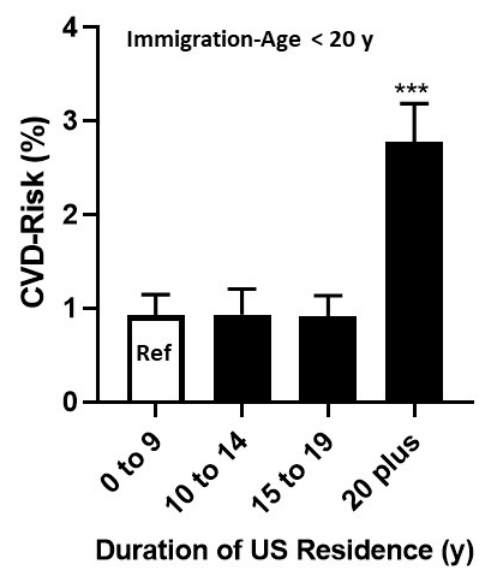

B

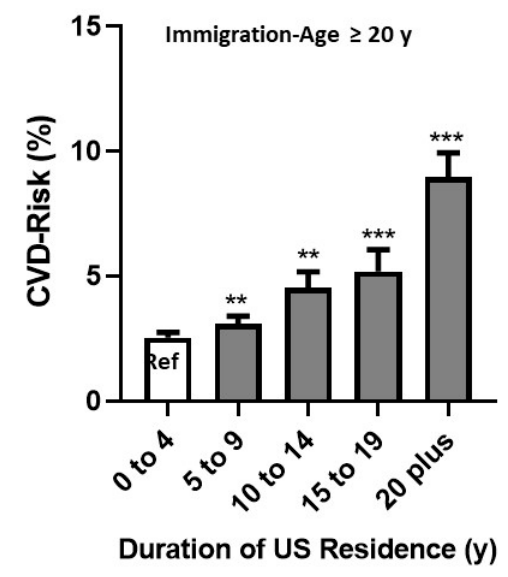

Figure 4. CVD-Risk by Duration of Residence in the United States for each Immigration-Age-Group. For both figures the first column is the reference group. ${ }^{* *} p<0.01,{ }^{* * *} p<0.001$. (A): Immigration-Age $<20$ y, (B): Immigration-Age $\geq 20 \mathrm{y}$.

For the Immigration-Age $\geq 20$ y group, adjusted $R^{2}$ was $41 \%$ (Table 4 ). The significant variables with positive $\beta$-coefficients were age at immigration, all $5 \mathrm{y}$ increments of duration of residence in the United States (Figure $4 \mathrm{~B}$ ), and alcohol intake (all $p<0.001$ ). The one significant variable with negative $\beta$-coefficient was income $(p=0.005)$. 
Table 4. Multiple Regression with CVD-Risk as the Dependent Variable in the Immigration-Age $\geq 20 \mathrm{y}$ Group. Adjusted $\mathrm{R}^{2}: 41 \%(n=368)^{1}$.

\begin{tabular}{lccc}
\hline \multicolumn{1}{c}{ Independent Variable } & $\boldsymbol{\beta}$-Coefficient & SE & $p$-Value \\
\hline Immigration Age & 0.271 & 0.027 & $<0.001$ \\
US residence 5 to $9 \mathrm{y}^{2}$ & 1.874 & 0.570 & 0.001 \\
US residence 10 to $14 \mathrm{y}^{2}$ & 2.548 & 0.643 & $<0.001$ \\
US residence 15 to $19 \mathrm{y}^{2}$ & 5.275 & 0.752 & $<0.001$ \\
US residence 20 y plus ${ }^{2}$ & 8.609 & 0.652 & $<0.001$ \\
Education & 0.180 & 0.161 & 0.262 \\
Health Insurance & 0.238 & 0.460 & 0.606 \\
Income & -0.323 & 0.115 & 0.005 \\
Alcohol Intake & 2.237 & 0.457 & $<0.001$ \\
\hline participants had missing data on duration of US residence. ${ }^{2}$ Reference group is US residence 0 to 4 y.
\end{tabular}

\section{Discussion}

To our knowledge, this is the first investigation to compare the cardiometabolic health status of African immigrants who came to the United States before age 20 years versus after age 20 years. We found that independent of francophone status or African region of origin (Supplement Tables S1-S4), African immigrants who had arrived in the United States before the age of 20 had similar or better cardiometabolic health than immigrants who arrived in the United States at age 20 or older (Table 1). Based on the metabolic, behavioral, and socioeconomic data collected, the cardiometabolic health of African immigrants who came to the United States before age 20 appears to be positively influenced by maintenance of African identity and the actualization of the socioeconomic advantages that come with immigration before adulthood. Furthermore, we sub-divided the Immigration-Age < 20 y group into two smaller age groups: before age nine and between age 10 and 19 years (Table 2). Our findings of a high degree of cultural identification, as demonstrated by self-identifying as African, and optimization of opportunity applied to both groups.

Evidence for cultural retention in the Immigration-Age $<20$ y group are provided by the observations that the majority of African immigrants who came to the United States before the age of $20 \mathrm{y}$ identified as African (Figure 3A), married African-born spouses, and did not acquire adverse health behaviors, such as smoking or drinking, at rates higher than immigrants who came to the United States as adults.

Home culture retention and family support in immigrant and indigenous communities are closely entwined [24]. Evidence linking cultural continuity in childhood to lower levels of stress, resilient behavior, and less cardiometabolic disease in adulthood was powerfully presented in a study by Currie et al. of indigenous adults living in Western Canada [24]. The value of family support on mitigating adverse cardiometabolic health was also evident in our earlier investigations in which we reported that immigrants who came to the United States for family reunification had lower allostatic loads than immigrants who were refugees or seeking asylum [3].

Furthermore, African immigrants who arrived as children may acquire behaviors in America that lead to improved health. African immigrants who arrived in America $<20$ years of age were more physically active in adulthood than immigrants who came as adults (Figure 3B). In men, this difference in physical activity level had a positive and potentially important physiological manifestation. HDL levels are known to increase with exercise and decrease CVD risk [25]. Even after adjusting for age, HDL and the associated apolipoprotein (apoA1) were higher in the immigrants who came before the age of $20 \mathrm{y}$. Interestingly, Evenson et al. reported that Latina immigrants who arrived in the United States before the age of 25 engaged in more physical activity in adulthood than Latina immigrants who arrived when they were older than 25 years [26].

Evidence for realizing opportunity in America by the Immigration-age $<20$ y group is demonstrated by the fact that $100 \%$ of the individuals who were college graduates in this group had obtained degrees 
from American universities compared to only $37 \%$ of college graduates in the Immigration-Age $\geq$ 20 y group. Compared to degrees obtained in Africa, Asia, or Europe, a degree from an American university may increase the opportunity for employment in the United States, which is commensurate with educational attainment. In addition, the benefit of health insurance is often linked to type of employment. Consistent with the concept that an American education and type of employment provides better health coverage, we found that immigrants who arrived before the age of $20 \mathrm{y}$ had health insurance at a higher rate than immigrants who arrived in the United States after age 20 (Figure 3D).

\subsection{CVD-Risk}

The multiple regression analyses revealed that the factors that contributed to an elevated CVD-Risk in the Immigration-Age $<20$ y group were age of immigration and more than 20 years residence in the United States (Table 3). For the Immigration-Age $\geq 20$ y group, the factors contributing to increased CVD-Risk were age of immigration, income, alcohol intake, and more than five years residence in the United States.

\subsubsection{Education and Income}

CVD-Risk was not influenced by education and income in the Immigration-Age $<20$ y group. It is likely that neither a college education nor a higher income lowered CVD-Risk in the Immigration-Age < 20 y group for the same reasons they do not contribute to lowering allostatic load in African-Americans. Please note that comparing the Immigration-Age $<20$ y group to African-Americans is fundamentally different than comparing the two immigration-age groups. After analyzing of National Health and Nutrition Examination Survey (NHANES) Data IV, Geronimus et al. reported that increased income in whites but not African-Americans led to a decrease in allostatic load [27]. Geronimus et al. attributed the inability of higher income to lower allostatic load score in African-Americans to the physiological consequence of coping with racism in America, a phenomenon the authors referred to as weathering [27]. In short, African immigrants who come to the United States as children will have life-time exposure to the same pressures and prejudices that African-Americans face.

In contrast, higher income in the Immigration-age $\geq 20$ y group was associated with a lower CVD-Risk. We speculate that the difference in the relationship between income and CVD-Risk Score in the two immigration age groups is related to remittances. For decades, the sending of money by immigrants to relatives in Africa has been considered a familial obligation of such magnitude that it represents a major form of international trade. According to the World Bank, in 2018, Nigerians received 24.2 billion dollars from overseas Nigerians, and this represented $6.1 \%$ of Nigeria's gross domestic product (GDP) [28]. In the same time frame, Ghanaian immigrants sent 3.8 billion dollars to relatives in Ghana, and this represented 7.3\% of Ghana's GDP [28]. The economic challenge of sending money to relatives in Africa is a major source of stress for African immigrants [29]. It is conceivable that a higher income may decrease the physiological stress induced by this financial obligation and decrease the risk of heart disease [30]. We did not collect data on remittance patterns, but we suspect that sending remittances to Africa is more common in the Immigration-Age $\geq 20 \mathrm{y}$ group than the Immigration-Age $<20$ y group.

\subsubsection{Alcohol Intake}

Alcohol intake promoted CVD-risk in the Immigration-Age $\geq 20 \mathrm{y}$ group, but not the Immigration-Age $<20$ y group. It is possible that the Immigration-Age $\geq 20$ y group consumes more alcohol per week than the Immigration-Age $<20$ y group. Our question about alcohol consumption inquires only whether a person has one or more drinks per week. Information on the upper limit is not requested. Our finding that greater alcohol consumption is associated with increased CVD in the immigration-Age $\geq 20$ group is consistent with the concept that immigration as an adult is stressful [31,32]. Stress promotes both cardiovascular disease and alcohol intake with the latter 
prompting the former [33]. Overall, we believe that members of the Immigration-Age $\geq 20 \mathrm{y}$ group immigrate more frequently in isolation and may have less social support than immigrants who arrive as children with their families.

\subsubsection{Duration of Residence}

Duration of stay in the United States was longer for the Immigration-Age $<20$ y group than the Immigration-Age $\geq 20$ y group (Figure 2), but the effect of duration of residence in the United States on the CVD-Risk was markedly different. For the Immigration-Age $<20$ y group, there was no effect of duration of residence on CVD-Risk until the stay in the United States was $\geq 20$ years (Figure 4A, Table 3). In a prospective analyses relating diabetes in adulthood to age of immigration in the foreign-born adults enrolled in the National Health Interview Survey Oza-Frank et al. also reported that for childhood immigrants the first two decades of life in the United States did not contribute to diabetes risk in adulthood [34].

In short, the first two decades of life in the United States do not appear to adversely affect the rate of heart disease in African immigrants who came to the United States as children.

However, the effect of duration of United States residence on CVD-Risk is different for adult immigrants. For the Immigration-Age $\geq 20$ y group, every 5 y increment ( 5 to 9 y, 10 to 14 y, 15 to 19 y and $20 \mathrm{y}$ plus) was associated with a highly significant increase in CVD-Risk. Again, Oza-Frank et al. had a similar finding for diabetes risk in foreign-born adults who came to the United States after age 18 [34].

Based on the findings of Oza-Frank et al. with diabetes and ours with CVD-Risk, we suggest that when duration of stay is related to immigrant health, age of immigration should be considered as a dichotomous variable (i.e., before or after age 20 y) [34]. If this is not done or not possible because of a lack of data on immigration age, conclusions about the effect of the first 20 years of residence in the United States on the risk for either CVD or diabetes will be confounded.

\subsection{Diverse Immigrant Populations}

Among the foreign-born populations in the United States, there is great diversity in ethnic identity, genetic background, reason for immigration, and the sociocultural, economic, and political realities of daily life. For many reasons, including differences in body mass index across population groups, our conclusions about the effect of age of immigration on the cardiovascular health of African immigrants may not be applicable to other immigrant groups of African descent such as Blacks from the Caribbean, United Kingdom, France, or Canada [35,36]. In addition, as our findings about African immigrant health are fundamentally different from reports in Hispanic and Asian immigrants [5,6,8,11-13], it is essential to not generalize about cardiometabolic health across immigrant populations.

\subsection{Strengths and Limitations}

The limitations of this study include the cross-sectional design, the lack of dietary data, the size of the cohort, and the use of a convenience sample. Nonetheless, there are characteristics of the cohort that give us confidence in both the size of the sample and its representative nature. Consistent with known immigration patterns, the majority of the participants were from non-francophone countries in West Africa [1]. Washington, DC, is a top settlement area for African immigrants in the United States [1]. In addition, our recruitment area included two of the five counties in the United States with the highest concentration of African-born Blacks, specifically Montgomery County, Maryland, and Prince George's County, Maryland [1]. Furthermore, and as would be expected in a representative sample, sickle cell trait and hemoglobin C were more common in West and Central Africans than East Africans [37,38]. The gender distribution of the cohort also followed expected patterns. The majority of immigrants who come from Africa to the United States as adults were male [1]. However, in the Immigrant-Age < 20 y group, $53 \%$ were male, which is consistent with the anticipated male-female ratio when families immigrate. In addition, the prevalence of diabetes in our cohort was $7 \%$, which is similar to the $9 \%$ 
prevalence of diabetes reported in African immigrants in Canada [39]. Equivalent data are not available in the United States.

However, about behaviors that increase cardiovascular risk, specifically smoking, we documented that only $5 \%$ of African immigrants smoked cigarettes, but we did not quantify the amount smoked. In addition, while we had educational data on all participants, we only collected information on location of degree granting institution in the most recently enrolled 74 participants.

\section{Conclusions}

African immigrants who came to the United States before the age of 20 years have, in adulthood, similar or even better cardiometabolic health than immigrants who arrived at 20 years or older. The likely reasons for why African immigrants who come to the United States age $<20$ y maintain their cardiometabolic health into adulthood are a strong sense of family and cultural identity; the failure to acquire adverse health behaviors; the adoption of positive behaviors, such as exercise; and the ability to optimize opportunities in America such as achieving an American college education and an occupation that provides health insurance. The health of immigrants is most often analyzed according to duration of residence in the United States. Yet our data suggests that the first 10 to 20 years of residence may have adverse health effects only on the African immigrants who came to the United States as adults. Going forward, we recommend analyzing the health of African immigrants from the perspective of age of immigration.

Supplementary Materials: The following are available online at http://www.mdpi.com/1660-4601/17/24/9405/s1, Table S1: Characteristics by African Region of Origin, Table S2: Characteristics According to Francophone Status of Country of Origin, Table S3: Characteristics by Immigration-Age-Group of Participants from Francophone Countries, Table S4: Characteristics by Immigration-Age-Group of Participants from Non-Francophone Countries.

Author Contributions: Conceptualization: E.M.S., T.H., N.H.O.-T., M.C.S.I., A.W., and A.E.S.; methodology: E.M.S., A.C.P., C.W.D., A.W., M.F.H.-R., and A.E.S.; software, E.M.S., T.H., M.F.H.-R., and A.E.S.; validation: E.M.S., A.W., M.F.H.-R., and A.E.S.; formal analysis: E.M.S., T.H., N.H.O.-T., M.C.S.I., A.C.P., M.F.H.-R., and A.E.S.; investigation: E.M.S., T.H., N.H.O.-T., C.W.D., A.C.P., M.F.H.-R., and A.E.S.; resources: A.E.S.; data curation: E.M.S., N.H.O.-T., and A.E.S.; writing-original draft preparation: E.M.S., T.H., and A.E.S.; writing-review and editing: E.M.S., T.H., N.H.O.-T., M.C.S.I., A.C.P., C.W.D., A.W., M.F.H.-R., and A.E.S.; visualization: A.E.S.; supervision: A.E.S.; project administration: C.W.D. and A.E.S.; funding acquisition: A.E.S. All authors have read and agreed to the published version of the manuscript.

Funding: The Intramural Programs of NIDDK and NIMHD.

Acknowledgments: E.M.S.: T.H., N.H.O.-T., M.C.S.I., A.C.P., C.W.D., A.W., and A.E.S. are supported by the intramural program of NIDDK. M.C.S.I. and A.E.S. are also supported by the intramural program of NIMHD. M.C.S.I. is also supported by the University of Global Health Equity, Kigali, Rwanda. A.C.P. is also supported by the NIH Academy Enrichment Program, Office of Intramural Training \& Education, NIH. M.F.H.-R. is supported by CUNY, New York.

Conflicts of Interest: The authors declare no conflict of interest.

\section{References}

1. Sub-Saharan African Immigrants in the United States. Available online: https:/www.migrationpolicy.org/ article/sub-saharan-african-immigrants-united-states (accessed on 28 October 2020).

2. African Immigrant Population in U.S. Steadily Climbs. Available online: https://www.pewresearch.org/facttank/2017/02/14/african-immigrant-population-in-u-s-steadily-climbs/ (accessed on 28 October 2020).

3. Hormenu, T.; Shoup, E.M.; Osei-Tutu, N.H.; Hobabagabo, A.F.; DuBose, C.W.; Mabundo, L.S.; Chung, S.T.; Horlyck-Romanovsky, M.F.; Sumner, A.E. Stress Measured by Allostatic Load Varies by Reason for Immigration, Age at Immigration, and Number of Children: The Africans in America Study. Int. J. Environ. Res. Public Health 2020, 17, 4533. [CrossRef] [PubMed]

4. Mukaz, D.K.; Melby, M.K.; Papas, M.A.; Setiloane, K.; Nmezi, N.A.; Commodore-Mensah, Y. Diabetes and acculturation in African immigrants to the United States: Analysis of the 2010-2017 National Health Interview Survey (NHIS). Ethn. Health 2020, 1-11. [CrossRef] 
5. Angel, R.J.; Angel, J.L.; Díaz Venegas, C.; Bonazzo, C. Shorter stay, longer life: Age at migration and mortality among the older Mexican-origin population. J. Aging Health 2010, 22, 914-931. [CrossRef] [PubMed]

6. Cedillo, Y.E.; Bertrand, B.; Baker, E.; Cherrington, A.L.; Beasley, T.M.; Fernández, J.R. Assimilation, Acculturation, and Allostatic Load in U.S.- and Foreign-Born Hispanics. J. Immigr. Minority Health 2020. [CrossRef] [PubMed]

7. McEwen, B.S. Protective and damaging effects of stress mediators. N. Engl. J. Med. 1998, 338, 171-179. [CrossRef] [PubMed]

8. Tang, T.S.; Halani, K.; Sohal, P.; Bains, P.; Khan, N. Do Cultural and Psychosocial Factors Contribute to Type 2 Diabetes Risk? A Look Into Vancouver's South Asian Community. Can. J. Diabetes 2020, 44, 14-21. [CrossRef]

9. D'Agostino, R.B.; Vasan, R.S.; Pencina, M.J.; Wolf, P.A.; Cobain, M.; Massaro, J.M.; Kannel, W.B. General cardiovascular risk profile for use in primary care: The Framingham Heart Study. Circulation 2008, 117, 743-753. [CrossRef]

10. Sewali, B.; Harcourt, N.; Everson-Rose, S.A.; Leduc, R.E.; Osman, S.; Allen, M.L.; Okuyemi, K.S. Prevalence of cardiovascular risk factors across six African Immigrant Groups in Minnesota. BMC Public Health 2015, 15, 411. [CrossRef]

11. Barr, R.G.; Avilés-Santa, L.; Davis, S.M.; Aldrich, T.K.; Gonzalez, F., 2nd; Henderson, A.G.; Kaplan, R.C.; LaVange, L.; Liu, K.; Loredo, J.S.; et al. Pulmonary Disease and Age at Immigration among Hispanics. Results from the Hispanic Community Health Study/Study of Latinos. Am. J. Respir. Crit. Care Med. 2016, 193, 386-395. [CrossRef]

12. Colón-López, V.; Haan, M.N.; Aiello, A.E.; Ghosh, D. The effect of age at migration on cardiovascular mortality among elderly Mexican immigrants. Ann. Epidemiol. 2009, 19, 8-14. [CrossRef]

13. Holmes, J.S.; Driscoll, A.K.; Heron, M. Mortality among US-born and immigrant Hispanics in the US: Effects of nativity, duration of residence, and age at immigration. Int. J. Public Health 2015, 60, 609-617. [CrossRef]

14. Briker, S.M.; Aduwo, J.Y.; Mugeni, R.; Horlyck-Romanovsky, M.F.; DuBose, C.W.; Mabundo, L.S.; Hormenu, T.; Chung, S.T.; Ha, J.; Sherman, A.; et al. A1C Underperforms as a Diagnostic Test in Africans Even in the Absence of Nutritional Deficiencies, Anemia and Hemoglobinopathies: Insight From the Africans in America Study. Front. Endocrinol. 2019, 10, 533. [CrossRef]

15. Hobabagabo, A.F.; Osei-Tutu, N.H.; Hormenu, T.; Shoup, E.M.; DuBose, C.W.; Mabundo, L.S.; Ha, J.; Sherman, A.; Chung, S.T.; Sacks, D.B.; et al. Improved Detection of Abnormal Glucose Tolerance in Africans: The Value of Combining Hemoglobin A(1c) With Glycated Albumin. Diabetes Care 2020, 43, 2607-2613. [CrossRef]

16. Kabakambira, J.D.; Baker, R.L., Jr.; Briker, S.M.; Courville, A.B.; Mabundo, L.S.; DuBose, C.W.; Chung, S.T.; Eckel, R.H.; Sumner, A.E. Do current guidelines for waist circumference apply to black Africans? Prediction of insulin resistance by waist circumference among Africans living in America. BMJ Glob. Health 2018, 3, e001057. [CrossRef] [PubMed]

17. O'Connor, M.Y.; Thoreson, C.K.; Ricks, M.; Courville, A.B.; Thomas, F.; Yao, J.; Katzmarzyk, P.T.; Sumner, A.E. Worse cardiometabolic health in african immigrant men than african american men: Reconsideration of the healthy immigrant effect. Metab. Syndr. Relat. Disord. 2014, 12, 347-353. [CrossRef] [PubMed]

18. World Health Organization. Available online: https://www.euro.who.int/en/health-topics/diseaseprevention/nutrition/a-healthy-lifestyle/body-mass-index-bmi (accessed on 28 October 2020).

19. American Diabetes Association. Classification and Diagnosis of Diabetes: Standards of Medical Care in Diabetes-2020. Diabetes Care 2020, 43 (Suppl. 1), S14-S31. [CrossRef] [PubMed]

20. D'Agostino, R.B.; Grundy, S.; Sullivan, L.M.; Wilson, P. Validation of the Framingham coronary heart disease prediction scores: Results of a multiple ethnic groups investigation. JAMA 2001, 286, 180-187. [CrossRef]

21. International Physical Activity Questionnaire. Available online: https://sites.google.com/site/theipaq/scoringprotocol (accessed on 28 October 2020).

22. Sumner, A.E.; Duong, M.T.; Bingham, B.A.; Aldana, P.C.; Ricks, M.; Mabundo, L.S.; Tulloch-Reid, M.K.; Chung, S.T.; Sacks, D.B. Glycated Albumin Identifies Prediabetes Not Detected by Hemoglobin A1c: The Africans in America Study. Clin. Chem. 2016, 62, 1524-1532. [CrossRef]

23. Harris, P.A.; Taylor, R.; Thielke, R.; Payne, J.; Gonzalez, N.; Conde, J.G. Research electronic data capture (REDCap)-A metadata-driven methodology and workflow process for providing translational research informatics support. J. Biomed. Inform. 2009, 42, 377-381. [CrossRef] 
24. Currie, C.L.; Copeland, J.L.; Metz, G.A. Childhood racial discrimination and adult allostatic load: The role of Indigenous cultural continuity in allostatic resiliency. Soc. Sci. Med. 2019, 241, 112564. [CrossRef]

25. Kodama, S.; Tanaka, S.; Saito, K.; Shu, M.; Sone, Y.; Onitake, F.; Suzuki, E.; Shimano, H.; Yamamoto, S.; Kondo, K.; et al. Effect of aerobic exercise training on serum levels of high-density lipoprotein cholesterol: A meta-analysis. Arch. Intern. Med. 2007, 167, 999-1008. [CrossRef]

26. Evenson, K.R.; Sarmiento, O.L.; Ayala, G.X. Acculturation and physical activity among North Carolina Latina immigrants. Soc. Sci. Med. 2004, 59, 2509-2522. [CrossRef]

27. Geronimus, A.T.; Hicken, M.; Keene, D.; Bound, J. “Weathering” and age patterns of allostatic load scores among blacks and whites in the United States. Am. J. Public Health 2006, 96, 826-833. [CrossRef] [PubMed]

28. Migration and Remittances Data (2020). Available online: https:/www.worldbank.org/en/topic/ migrationremittancesdiasporaissues/brief/migration-remittances-data (accessed on 28 October 2020).

29. Afulani, P.A.; Torres, J.M.; Sudhinaraset, M.; Asunka, J. Transnational ties and the health of sub-Saharan African migrants: The moderating role of gender and family separation. Soc. Sci. Med. 2016, 168, 63-71. [CrossRef] [PubMed]

30. Moran, K.E.; Ommerborn, M.J.; Blackshear, C.T.; Sims, M.; Clark, C.R. Financial Stress and Risk of Coronary Heart Disease in the Jackson Heart Study. Am. J. Prev. Med. 2019, 56, 224-231. [CrossRef] [PubMed]

31. Pinedo, M.; Valdez, C.R. Immigration Enforcement Policies and the Mental Health of US Citizens: Findings from a Comparative Analysis. Am. J. Community Psychol. 2020, 66, 119-129. [CrossRef]

32. Cano, M.; Sánchez, M.; Trepka, M.J.; Dillon, F.R.; Sheehan, D.M.; Rojas, P.; Kanamori, M.J.; Huang, H.; Auf, R.; De La Rosa, M. Immigration Stress and Alcohol Use Severity Among Recently Immigrated Hispanic Adults: Examining Moderating Effects of Gender, Immigration Status, and Social Support. J. Clin. Psychol. 2017, 73, 294-307. [CrossRef]

33. Lee, H.; Singh, G.K. Psychological Distress and Heart Disease Mortality in the United States: Results from the 1997-2014 NHIS-NDI Record Linkage Study. Int. J. Matern. Child Health AIDS 2020, 9, 260-273. [CrossRef]

34. Oza-Frank, R.; Stephenson, R.; Narayan, K.M. Diabetes prevalence by length of residence among US immigrants. J. Immigr. Minority Health 2011, 13, 1-8. [CrossRef]

35. Horlyck-Romanovsky, M.F.; Fuster, M.; Echeverria, S.E.; Wyka, K.; Leung, M.M.; Sumner, A.E.; Huang, T.T. Black Immigrants from Africa and the Caribbean Have Similar Rates of Diabetes but Africans Are Less Obese: The New York City Community Health Survey 2009-2013. J. Racial Ethn. Health Disparities 2019, 6, 635-645. [CrossRef]

36. Utumatwishima, J.N.; Chung, S.T.; Bentley, A.R.; Udahogora, M.; Sumner, A.E. Reversing the tide-Diagnosis and prevention of T2DM in populations of African descent. Nat. Rev. Endocrinol. 2018, 14, 45-56. [CrossRef] [PubMed]

37. Piel, F.B.; Howes, R.E.; Patil, A.P.; Nyangiri, O.A.; Gething, P.W.; Bhatt, S.; Williams, T.N.; Weatherall, D.J.; Hay, S.I. The distribution of haemoglobin C and its prevalence in newborns in Africa. Sci. Rep. 2013, 3, 1671. [CrossRef] [PubMed]

38. Piel, F.B.; Patil, A.P.; Howes, R.E.; Nyangiri, O.A.; Gething, P.W.; Dewi, M.; Temperley, W.H.; Williams, T.N.; Weatherall, D.J.; Hay, S.I. Global epidemiology of sickle haemoglobin in neonates: A contemporary geostatistical model-based map and population estimates. Lancet 2013, 381, 142-151. [CrossRef]

39. Creatore, M.I.; Moineddin, R.; Booth, G.; Manuel, D.H.; DesMeules, M.; McDermott, S.; Glazier, R.H. Ageand sex-related prevalence of diabetes mellitus among immigrants to Ontario, Canada. CMAJ 2010, 182, 781-789. [CrossRef] [PubMed]

Publisher's Note: MDPI stays neutral with regard to jurisdictional claims in published maps and institutional affiliations.

(C) 2020 by the authors. Licensee MDPI, Basel, Switzerland. This article is an open access article distributed under the terms and conditions of the Creative Commons Attribution (CC BY) license (http://creativecommons.org/licenses/by/4.0/). 